\title{
Sphingopyxis bauzanensis sp. nov., a psychrophilic bacterium isolated from soil
}

\author{
Correspondence \\ Rosa Margesin \\ Rosa.Margesin@uibk.ac.at
}

\author{
De-Chao Zhang, ${ }^{1}$ Hong-Can Liu, ${ }^{2}$ Yu-Hua Xin, ${ }^{2}$ Yu-Guang Zhou, ${ }^{2}$ \\ Franz Schinner ${ }^{1}$ and Rosa Margesin ${ }^{1}$
}

\author{
${ }^{1}$ Institute of Microbiology, University of Innsbruck, Technikerstrasse 25, A-6020 Innsbruck, Austria \\ ${ }^{2}$ China General Microbiological Culture Collection Center and State Key Laboratory of Microbial \\ Resources, Institute of Microbiology, Chinese Academy of Sciences, Beijing 100101, PR China
}

The genus Sphingomonas was first proposed by Yabuuchi et al. (1990), with five species and two genomospecies. Based on phylogenetic, chemotaxonomic and physiological analyses, the genus Sphingomonas has been divided into four genera: Sphingomonas, Sphingobium, Novosphingobium and Sphingopyxis (Takeuchi et al., 2001). These four genera differ in their polyamine patterns, nucleotide signatures and some phenotypic characteristics (e.g. ability or inability for nitrate reduction) and were separated into four clusters (I-IV) based on distance matrix analysis of 16S rRNA gene sequences (Takeuchi et al., 2001). However, Yabuuchi et al. (2002) emphasized that the three proposed genera, Sphingobium, Novosphingobium and Sphingopyxis, should be considered as later homotypic synonyms of species of the genus Sphingomonas because there is no phenotypic and phylogenetic evidence. So far the nomenclature of Takeuchi et al. (2001) is generally used (Busse et al., 2003; Yoon \& Oh, 2005). At the time of writing, the genus Sphingopyxis comprises 12 species: Sphingopyxis macrogoltabida (Takeuchi et al., 1993, 2001), Sphingopyxis

The GenBank/EMBL/DDBJ accession number for the $16 \mathrm{~S}$ rRNA gene sequence of strain $B Z 30^{\top}$ is GQ131578.

Cellular fatty acid compositions and a two-dimensional thin-layer chromatogram of polar lipids of strain $\mathrm{BZ}^{\top} \mathrm{O}^{\top}$ are available with the online version of this paper. terrae (Takeuchi et al., 1993, 2001), Sphingopyxis taejonensis (Lee et al., 2001; Pal et al., 2006), Sphingopyxis witflariensis (Kämpfer et al., 2002), Sphingopyxis alaskensis (Vancanneyt et al., 2001; Godoy et al., 2003), Sphingopyxis chilensis (Godoy et al., 2003), 'Sphingopyxis granuli' (Kim et al., 2005), Sphingopyxis flavimaris (Yoon \& Oh, 2005), Sphingopyxis baekryungensis (Yoon et al., 2005), Sphingopyxis ginsengisoli (Lee et al., 2008), Sphingopyxis litoris and Sphingopyxis marina (Kim et al., 2008). The type strains of these species have been isolated from various environmental sources, such as soil, sludge, sediment, seawater and mineral water. In this study, we report on the characterization of a novel, psychrophilic bacterium of the genus Sphingopyxis isolated from soil from an industrial site contaminated with hydrocarbons.

Strain $\mathrm{BZ}^{\mathrm{T}}{ }^{\mathrm{T}}$ was isolated from soil from an industrial site containing high amounts of heavy oil and located in Bozen, South Tyrol, Italy. The soil was collected under sterile conditions in spring 2008. A $10 \mathrm{~g}$ sample was shaken with $90 \mathrm{ml}$ of sterile $1 \%$ sodium pyrophosphate for $20 \mathrm{~min}$ at 150 r.p.m. Appropriate dilutions, prepared with sterile saline solution $(0.9 \% \mathrm{NaCl})$, were plated on $\mathrm{R}_{2} \mathrm{~A}$ agar incubated at $20{ }^{\circ} \mathrm{C}$. One of the pure cultures was yellowpigmented and was designated $\mathrm{BZ} 30^{\mathrm{T}}$. 
Sphingopyxis witflariensis $\mathrm{W}-50^{\mathrm{T}}$, Sphingopyxis ginsengisoli LMG $23390^{\mathrm{T}}$, Sphingopyxis taejonensis DSM $15583^{\mathrm{T}}$ and Sphingopyxis chilensis DSM $14889^{\mathrm{T}}$ shared the highest sequence similarities with strain $\mathrm{BZ} 30^{\mathrm{T}}$ and were thus used as reference strains for DNA-DNA hybridization and for analysis of phenotypic parameters and fatty acid composition. They were routinely grown in nutrient broth $(0.3 \%$ yeast extract, $0.5 \%$ peptone; Merck) at $25{ }^{\circ} \mathrm{C}$.

DNA was extracted and purified as described by Sambrook et al. (1989). The gene encoding 16S rRNA was amplified by PCR with two universal primers (Zhang et al., 2006). PCR products were cloned in pGEM-T vectors using the pGEM-T easy vector system (Promega) according to the manufacturer's instructions. Sequencing reactions and phylogenetic analysis were performed as described by Zhang et al. (2006). Phylogenetic analysis based on a consensus $1314 \mathrm{bp}$ length of $16 \mathrm{~S}$ rRNA gene sequences showed that strain $\mathrm{BZ}^{\mathrm{T}} 0^{\mathrm{T}}$ grouped with members of the genus Sphingopyxis (Fig. 1) and formed a cluster with Sphingopyxis witflariensis $\mathrm{W}-50^{\mathrm{T}}$, Sphingopyxis chilensis LMG $20986^{\mathrm{T}}$ and Sphingopyxis taejonensis KCTC $2884^{\mathrm{T}}$. The highest sequence similarities were shown with the type strains of Sphingopyxis chilensis (98.3\%), Sphingopyxis witflariensis (98.2\%), Sphingopyxis taejonensis (97.4\%) and Sphingopyxis ginsengisoli (97.2\%). Similar tree topologies were found in the trees generated with the maximum-parsimony and maximum-likelihood algorithms (data not shown). Nucleotide signatures specific to the $16 \mathrm{~S}$ rRNA of strain $\mathrm{BZ} 30^{\mathrm{T}}$ were the same as those of the genus Sphingopyxis (Cluster IV) reported by Takeuchi et al. (2001), i.e. $\mathrm{C}-\mathrm{G}$ at position 52:359, $\mathrm{G}$ at position 134, $\mathrm{U}$ at position 593, G-C at position $987: 1218$ and $\mathrm{U}-\mathrm{G}$ at position 990:1215 (Escherichia coli numbering; Brosius et al., 1978).

Strain $\mathrm{BZ} 30^{\mathrm{T}}$ was routinely cultured in the low-strength medium $\mathrm{R}_{2} \mathrm{~A}$ at $20{ }^{\circ} \mathrm{C}$ and maintained as a suspension in skim milk $(10 \%, \mathrm{w} / \mathrm{v})$ at $-80{ }^{\circ} \mathrm{C}$. The cell morphology was examined by phase-contrast microscopy $(\times 1000)$ of cells grown on $\mathrm{R}_{2} \mathrm{~A}$ agar plates at $20{ }^{\circ} \mathrm{C}$. The colonial morphology was also observed on $\mathrm{R}_{2} \mathrm{~A}$ agar plates. The API M system (bioMérieux) was used to evaluate cell motility. Gram-reaction was tested by classical Gramstaining and was confirmed by the $\mathrm{KOH}$-lysis test. Catalase activity was determined by bubble production in $3 \%(\mathrm{v} / \mathrm{v})$ $\mathrm{H}_{2} \mathrm{O}_{2}$; oxidase activity was determined using $1 \%(\mathrm{w} / \mathrm{v})$ $N, N, N^{\prime}, N^{\prime}$-tetramethyl-p-phenylenediamine. API strips (API 20 E, API 20 NE, API ZYM; bioMérieux) incubated at $25{ }^{\circ} \mathrm{C}$ were used according to the manufacturer's instructions to determine physiological and biochemical characteristics as well as enzyme activities of strain $\mathrm{BZ} 30^{\mathrm{T}}$ and of the four reference strains Sphingopyxis witflariensis $\mathrm{W}-50^{\mathrm{T}}$, Sphingopyxis ginsengisoli LMG $23390^{\mathrm{T}}$, Sphingopyxis taejonensis DSM $15583^{\mathrm{T}}$ and Sphingopyxis chilensis DSM $14889^{\mathrm{T}}$. Activities of $\beta$-galactosidase, amylase and protease were additionally tested by using $\mathrm{R}_{2} \mathrm{~A}$ agar plates supplemented with appropriate substrates (Margesin

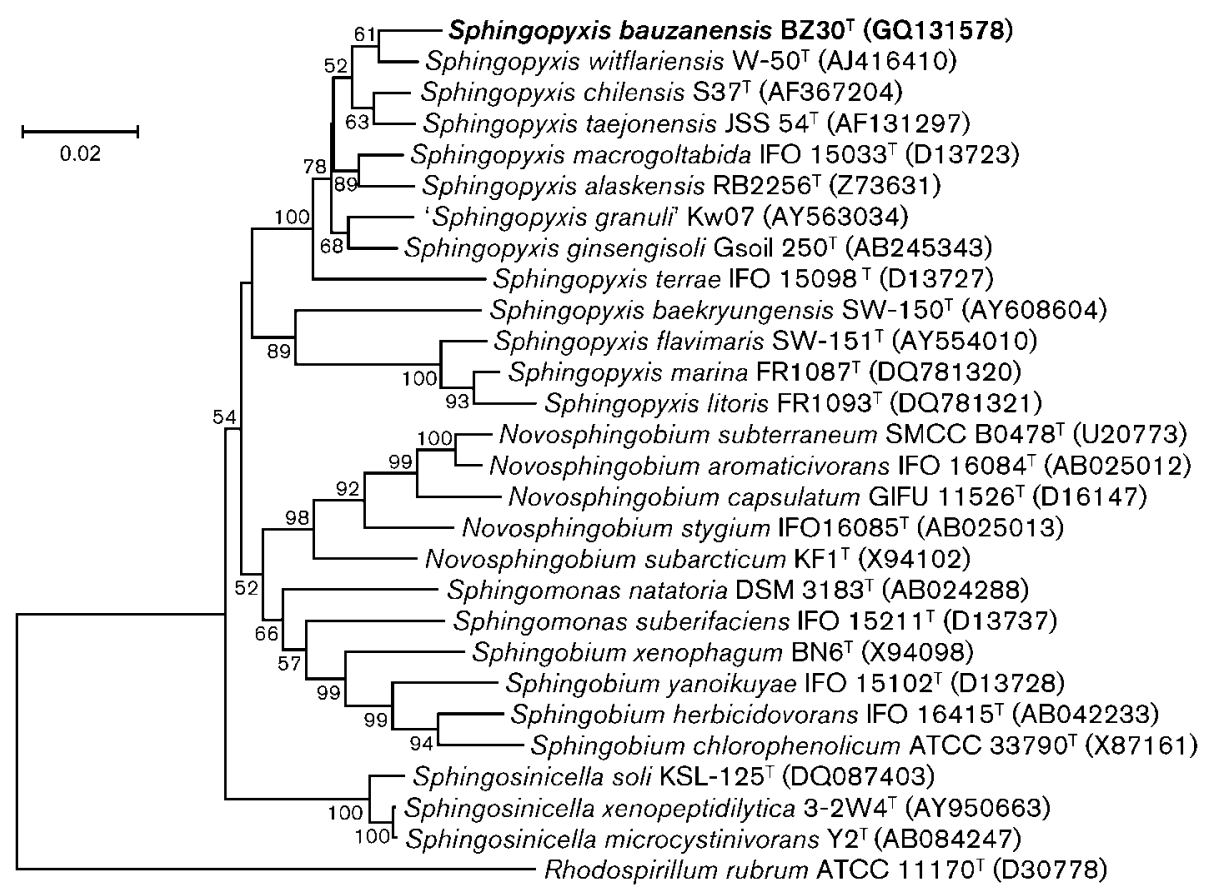

Fig. 1. Phylogenetic relationship of strain $B Z 30^{\top}$ and related genera based on $16 \mathrm{~S}$ rRNA gene sequence data (neighbourjoining method). Bootstrap values (expressed as percentages of 1000 replicates) greater than $50 \%$ are shown at branch points. Rhodospirillum rubrum ATCC $11170^{\top}$ was used as the outgroup. GenBank accession numbers of $16 \mathrm{~S}$ rRNA sequences are given in parentheses. Bar, $2 \%$ sequence divergence. 
et al., 2003). Gelatinase activity was tested on Nutrient Gelatin ( $0.3 \%$ beef extract, $0.5 \%$ peptone, $12 \%$ gelatin; Difco). Growth at different temperatures $\left(1-37^{\circ} \mathrm{C}\right)$ was assessed on $\mathrm{R}_{2} \mathrm{~A}$ agar plates and in $\mathrm{R}_{2} \mathrm{~A}$ liquid medium at 150 r.p.m. Growth at various $\mathrm{pH}$ (5-9) and salt tolerance $[0-10 \%(\mathrm{w} / \mathrm{v}) \mathrm{NaCl}]$ were determined on $\mathrm{R}_{2} \mathrm{~A}$ agar plates. Antibiotic susceptibility was determined on $\mathrm{R}_{2} \mathrm{~A}$ agar plates supplemented with various antibiotics and incubated at $20{ }^{\circ} \mathrm{C}$. Morphological, physiological and biochemical characteristics of strain $\mathrm{BZ}^{\mathrm{T}}{ }^{\mathrm{T}}$ are given in the species description (see below) and are shown in Table 1 . The features that serve to differentiate strain $\mathrm{BZ}^{\mathrm{T}}{ }^{\mathrm{T}}$ from the phylogenetically most closely related members of the genus Sphingopyxis are given in Table 1.

Respiratory quinones were extracted and purified according to Collins (1985) and were analysed by HPLC (Wu et al., 1989). The cellular polar lipids were extracted and analysed on silica gel plates (Kieselgel 60 F; Merck) by TLC (Kates, 1986). Glycolipid spots were detected by spraying the plate with $0.5 \%(\mathrm{w} / \mathrm{v}) \alpha$-naphthol in $50 \%(\mathrm{v} / \mathrm{v})$ methanol, followed by spraying with $50 \%$ sulfuric acid/
$50 \%$ ethanol (v/v) and heating at $120{ }^{\circ} \mathrm{C}$ for $5 \mathrm{~min}$. Phospholipids were visualized with the Zinzadze reagent (Kates, 1986). Total lipids were stained with $5 \%(\mathrm{w} / \mathrm{v})$ ethanolic molybdatophosphoric acid spray. For polyamine analysis, strain $B Z 30^{\mathrm{T}}$ was grown in modified $\mathrm{R}_{2} \mathrm{~A}$ medium (without starch) since it was not able to grow in PYE medium $(0.3 \%$ yeast extract, $0.3 \%$ peptone, $\mathrm{pH} 7)$ or in diluted (1:3 or $1: 6)$ PYE medium, which is commonly used to determine polyamine patterns. Polyamines were extracted and analysed as described by Busse \& Auling (1988), Busse et al. (1997) and Stolz et al. (2007).

Strain $\mathrm{BZ}^{\mathrm{T}}{ }^{\mathrm{T}}$ contained $\mathrm{Q}-10$ as the major ubiquinone. Major polar lipids were sphingoglycolipids, diphosphatidylglycerol, phosphatidylglycerol, phosphatidylethanolamine and phosphatidylcholine. Small amounts of phosphatidylmonomethylethanolamine and an unidentified glycolipid are also present (see two-dimensional thin-layer chromatogram available as Supplementary Fig. S1 in IJSEM Online). Spermidine was the major polyamine component (17.1 $\mu \mathrm{mol} \mathrm{g}^{-1}$ dry mass), whereas 1,3-diaminopropane and putrescine were detected in only small amounts ( 0.3 and

Table 1. Phenotypic characteristics that differentiate strain $B Z 30^{\top}$ from closely related species of the genus Sphingopyxis

Strains: 1, Sphingopyxis bauzanensis sp. nov. BZ30 ${ }^{\mathrm{T}} ; 2$, Sphingopyxis chilensis DSM $14889^{\mathrm{T}} ; 3$, Sphingopyxis ginsengisoli $\mathrm{LMG} 23390^{\mathrm{T}}$; 4 , Sphingopyxis taejonensis DSM $15583^{\mathrm{T}} ; 5$, Sphingopyxis witflariensis DSM $14551^{\mathrm{T}}$. All data from this study. All species are Gram-negative, rod-shaped, non-sporeforming, motile, positive for activities of catalase, oxidase, acid phosphatase, alkaline phosphatase, esterase (C4), esterase lipase (C8), leucine arylamidase and naphthol-AS-BI-phosphohydrolase, and assimilate glucose. All species are negative for nitrate reduction, indole production, hydrolysis of urea and gelatin, activities of lipase (C14), $\alpha$-galactosidase, $\beta$-glucuronidase, $N$-acetyl- $\beta$-glucosaminidase, $\alpha$-mannosidase and $\alpha$-fucosidase, assimilation of citrate, $N$-acetylglucosamine and phenylacetic acid, and for fermentative metabolism. + , Positive; w, weakly positive; - , negative.

\begin{tabular}{|c|c|c|c|c|c|}
\hline Characteristic & 1 & 2 & 3 & 4 & 5 \\
\hline Isolation source & $\begin{array}{c}\text { Contaminated soil } \\
\text { (Italy) }\end{array}$ & $\begin{array}{c}\text { Contaminated river } \\
\text { sediment (Chile) }\end{array}$ & $\begin{array}{l}\text { Soil from ginseng } \\
\text { field (South Korea) }\end{array}$ & $\begin{array}{c}\text { Natural mineral } \\
\text { water (South } \\
\text { Korea) }\end{array}$ & $\begin{array}{l}\text { Activated sludge from } \\
\text { wastewater plant } \\
\text { (Germany) }\end{array}$ \\
\hline $\begin{array}{l}\text { Growth temperature range } \\
\left({ }^{\circ} \mathrm{C}\right)^{*}\end{array}$ & $1-30$ & $1-37$ & $10-37$ & $\begin{array}{c}10-37 \\
\text { (weak at 5) }\end{array}$ & $1-30$ \\
\hline $\begin{array}{l}\text { Growth in presence of } 7.5 \% \\
(\mathrm{w} / \mathrm{v}) \mathrm{NaCl}{ }^{*}\end{array}$ & - & + & - & - & - \\
\hline \multicolumn{6}{|l|}{ Enzyme activites $\left(25^{\circ} \mathrm{C}\right)$} \\
\hline Hydrolysis of aesculin & + & + & + & - & - \\
\hline Arginine dihydrolase & - & - & + & - & - \\
\hline Cystine arylamidase & - & + & + & + & + \\
\hline Trypsin & - & - & + & - & + \\
\hline$\alpha$-Chymotrypsin & - & - & + & - & - \\
\hline$\alpha$-Glucosidase & + & + & - & + & - \\
\hline \multicolumn{6}{|l|}{ Assimilation of $\left(25^{\circ} \mathrm{C}\right)$ : } \\
\hline L-Arabinose & - & + & - & - & - \\
\hline D-Mannitol & - & + & - & - & - \\
\hline Maltose & + & + & + & - & + \\
\hline D-Mannose & - & $\mathrm{W}$ & - & - & - \\
\hline Potassium gluconate & - & + & - & - & - \\
\hline Capric acid & - & - & - & $\mathrm{W}$ & + \\
\hline Malic acid & + & - & + & + & - \\
\hline
\end{tabular}

${ }^{\star}$ Data obtained on $\mathrm{R}_{2} \mathrm{~A}$ agar plates. 
$0.2 \mu \mathrm{mol} \mathrm{g}^{-1}$ dry mass, respectively). Cadaverine and spermine were detected in trace amounts $\left(<0.1 \mu \mathrm{mol} \mathrm{g}{ }^{-1}\right.$ dry mass). This polyamine pattern is in agreement with the characteristics of members of the genus Sphingopyxis (Busse et al., 1999; Takeuchi et al., 2001).

For fatty acid methyl ester analysis, strain $\mathrm{BZ} 30^{\mathrm{T}}$ and two reference strains (Sphingopyxis witflariensis $\mathrm{W}-50^{\mathrm{T}}$ and Sphingopyxis chilensis DSM $14889^{\mathrm{T}}$ ) were grown on tryptic soy agar plates (TSA) at $25{ }^{\circ} \mathrm{C}$ for 3 days. The fatty acid methyl esters were extracted and prepared according to the standard protocol of the MIDI (Microbial Identification) system (Sasser, 1990). The predominant cellular fatty acids of strain $\mathrm{BZ30}^{\mathrm{T}}$ were summed feature $3\left(\mathrm{C}_{16: 1} \omega 7 \mathrm{c}\right.$ and/or iso- $\left.\mathrm{C}_{15: 0} 2-\mathrm{OH}\right)(37.4 \%), \mathrm{C}_{18: 1} \omega 7 c(19.6 \%), \mathrm{C}_{16: 0}(8.2 \%)$, $\mathrm{C}_{14: 0} 2-\mathrm{OH}(8.0 \%)$ and $\mathrm{C}_{16: 0} 2-\mathrm{OH}(5.0 \%)$; this fatty acid profile was in agreement with those of other species of the genus Sphingopyxis (Kämpfer et al., 2002; Godoy et al., 2003; Lee et al., 2008). The fatty acid profiles of strain $\mathrm{BZ}^{2} 0^{\mathrm{T}}$ and other species of the genus Sphingopyxis are available as Supplementary Table S1.

The DNA G $+\mathrm{C}$ content was determined by the thermal denaturation method with Escherichia coli $\mathrm{K}-12$ as the reference, and DNA-DNA hybridization was done by the liquid renaturation method (De Ley et al., 1970) as modified by Huß et al. (1983); both experiments were carried out using a model Lambda 35 UV/VIS spectrometer equipped with a temperature program controller (Perkin-Elmer). The DNA G $+\mathrm{C}$ content of strain $\mathrm{BZ}^{\mathrm{T}}{ }^{\mathrm{T}}$ was $64.4 \mathrm{~mol} \%$. The DNA-DNA relatedness between strain $\mathrm{BZ}^{\mathrm{T}}{ }^{\mathrm{T}}$ and Sphingopyxis chilensis DSM $14889^{\mathrm{T}}$, Sphingopyxis witflariensis $\mathrm{W}-50^{\mathrm{T}}$, Sphingopyxis ginsengisoli LMG $23390^{\mathrm{T}}$ and Sphingopyxis taejonensis DSM $15583^{\mathrm{T}}$ was $21.2,20.3,19.9$ and $18.4 \%$, respectively. These values are below the threshold value (approx. 70\%) for possible relatedness at the species level (Wayne et al., 1987).

Bacteria belonging to the genus Sphingopyxis are Gramnegative, non-fermentative, aerobic, non-spore-forming, yellow-pigmented or whitish-brown, catalase- and oxidasepositive, contain the ubiquinone Q-10 and sphingoglycolipids, and have a DNA G $+\mathrm{C}$ content of $63-69 \mathrm{~mol} \%$ (Godoy et al., 2003; Lee et al., 2008). Strain $\mathrm{BZ}^{\mathrm{T}}{ }^{\mathrm{T}}$ displayed all of these properties. In addition, nucleotide signatures and some important phenotypic characteristics, such as the polyamine pattern and the inability to reduce nitrate, further confirmed the taxonomic position of strain $\mathrm{BZ}^{2} 0^{\mathrm{T}}$ as determined by phylogenetic analysis. The strain is a psychrophilic (cold-adapted) representative of the genus Sphingopyxis, showing good growth at $1-25{ }^{\circ} \mathrm{C}$. Based on phylogenetic, phenotypic and genomic evidence, strain ${\mathrm{BZ} 30^{\mathrm{T}}}^{\mathrm{T}}$ was identified as a representative of a novel species of the genus Sphingopyxis, for which the name Sphingopyxis bauzanensis sp. nov. is proposed.

\section{Description of Sphingopyxis bauzanensis sp. nov.}

Sphingopyxis bauzanensis (bau.zan.en'sis. M.L. fem. adj. bauzanensis referring to Bauzanum, the medieval Latin name for Bozen/Bolzano, a city in South Tyrol, Italy, where the type strain was first found).

Cells are Gram-negative, aerobic, rod-shaped (0.4-0.6 $\times 0.8-$ $1.1 \mu \mathrm{m})$ and motile. Colonies on $\mathrm{R}_{2} \mathrm{~A}$ agar are yellow, round, convex and with entire margin; colony diameter is approximately $1 \mathrm{~mm}$ after 6 days at $20^{\circ} \mathrm{C}$ on $\mathrm{R}_{2} \mathrm{~A}$ agar. Growth occurs in liquid $\mathrm{R}_{2} \mathrm{~A}$ medium and on agar plates at $1-30{ }^{\circ} \mathrm{C}$; growth rate is fastest at $25{ }^{\circ} \mathrm{C}$ and absent at $37{ }^{\circ} \mathrm{C}$; good growth occurs at $1-5{ }^{\circ} \mathrm{C}$. On $\mathrm{R}_{2} \mathrm{~A}$ agar plates, grows at pH 6-8 and in the presence of $0-3 \%(w / v) ~ N a C l$. Produces catalase and cytochrome oxidase. Positive for hydrolysis of aesculin and for activities of alkaline phosphatase, acid phosphatase, esterase (C4), esterase lipase (C8), leucine arylamidase, naphthol-AS-BI-phosphohydrolase and $\alpha$-glucosidase. Negative for nitrate reduction, production of indole (tryptophan deaminase activity) and $\mathrm{H}_{2} \mathrm{~S}$, citrate utilization, and hydrolysis of urea, starch, gelatin and Tween 80 . Negative for activities of arginine dihydrolase, lysine dihydrolase, ornithine dihydrolase, lipase (C14), cystine arylamidase, $\beta$-glucosidase, $\alpha$-galactosidase, $\beta$-galactosidase, $\beta$-glucuronidase, $N$-acetyl- $\beta$-glucosaminidase, trypsin, $\alpha$ chymotrypsin, $\alpha$-fucosidase and $\alpha$-mannosidase. Assimilates D-glucose, maltose and malic acid, but does not assimilate Larabinose, citrate, D-mannose, D-mannitol, $\mathrm{N}$-acetylglucosamine, potassium gluconate, capric acid or phenylacetic acid as sole carbon sources. Negative for fermentation of glucose, ribose, xylose, mannitol, maltose, lactose, sucrose, glycogen, inositol, sorbitol, rhamnose, melibiose, amygdalin and Larabinose. Sensitive to ampicillin $\left(50 \mu \mathrm{g} \mathrm{ml}^{-1}\right)$, penicillin $\mathrm{G}$, tetracycline, chloramphenicol, rifampicin and trimethoprim (each $\left.100 \mu \mathrm{g} \mathrm{ml}^{-1}\right)$, but resistant to streptomycin $(100 \mu \mathrm{g}$ $\mathrm{ml}^{-1}$ ) and cyclosporin $\mathrm{A}\left(100 \mu \mathrm{g} \mathrm{ml}^{-1}\right)$. Growth in presence of kanamycin $\left(100 \mu \mathrm{g} \mathrm{ml}^{-1}\right)$ is delayed. Q-10 is the major ubiquinone. The predominant cellular fatty acids are summed feature $3\left(\mathrm{C}_{16: 1} \omega 7 c\right.$ and/or iso- $\mathrm{C}_{15: 0}$ 2-OH), $\mathrm{C}_{18: 1} \omega 7 c, \mathrm{C}_{16: 0}, \mathrm{C}_{14: 0} 2-\mathrm{OH}$ and $\mathrm{C}_{16: 0} 2-\mathrm{OH}$. Major polar lipids are sphingoglycolipids, diphosphatidylglycerol, phosphatidylglycerol, phosphatidylethanolamine and phosphatidylcholine. Spermidine is the major polyamine. The $\mathrm{G}+\mathrm{C}$ content of the genomic DNA is $64.4 \mathrm{~mol} \%$.

The type strain is $\mathrm{BZ}^{\mathrm{T}}{ }^{\mathrm{T}}\left(=\mathrm{DSM} 22271^{\mathrm{T}}=\mathrm{CGMCC}\right.$ $1.8959^{\mathrm{T}}=\mathrm{CIP} 110136^{\mathrm{T}}$ ) and was isolated from hydrocarbon-contaminated soil in Bozen, South Tyrol, Italy.

\section{Acknowledgements}

This research work was supported by a research grant from the 'Autonome Provinz Bozen, Südtirol'. We thank P. Thurbichler for technical assistance, Dr H.-J. Busse for polyamine analysis and Dr P. Kämpfer for providing us with the type strain of Sphingopyxis witflariensis.

\section{References}

Brosius, J., Palmer, M. L., Kennedy, P. J. \& Noller, H. F. (1978). Complete nucleotide sequence of a $16 \mathrm{~S}$ ribosomal RNA gene from Escherichia coli. Proc Natl Acad Sci U S A 75, 4801-4805. 
Busse, H.-J. \& Auling, G. (1988). Polyamine pattern as a chemotaxonomic marker within the Proteobacteria. Syst Appl Microbiol 11, 1-8.

Busse, H.-J., Bunka, S., Hensel, A. \& Lubitz, W. (1997). Discrimination of members of the family Pasteurellaceae based on polyamine patterns. Int J Syst Bacteriol 47, 698-708.

Busse, H.-J., Kämpfer, P. \& Denner, E. B. M. (1999). Chemotaxonomic characterisation of Sphingomonas. J Ind Microbiol Biotechnol 23, 242-251.

Busse, H.-J., Denner, E. B. M., Buczolits, S., Salkinoja-Salonen, M., Bennasar, A. \& Kämpfer, P. (2003). Sphingomonas aurantiaca sp. nov., Sphingomonas aerolata sp. nov. and Sphingomonas faeni sp. nov., air- and dustborne and Antarctic, orange-pigmented, psychrotolerant bacteria, and emended description of the genus Sphingomonas. Int $J$ Syst Evol Microbiol 53, 1253-1260.

Collins, M. D. (1985). Isoprenoid quinone analysis in classification and identification. In Chemical Methods in Bacterial Systematics, pp. 267-287. Edited by M. Goodfellow \& D. E. Minnikin. London: Academic Press.

De Ley, J., Cattoir, H. \& Reynaerts, A. (1970). The quantitative measurement of DNA hybridization from renaturation rates. Eur $J$ Biochem 12, 133-142.

Godoy, F., Vancanneyt, M., Martínez, M., Steinbüchel, A., Swings, J. \& Rehm, B. H. A. (2003). Sphingopyxis chilensis sp. nov., a chlorophenol-degrading bacterium that accumulates polyhydroxyalkanoate, and transfer of Sphingomonas alaskensis to Sphingopyxis alaskensis comb. nov. Int J Syst Evol Microbiol 53, 473-477.

Huß, V. A. R., Festl, H. \& Schleifer, K. H. (1983). Studies on the spectrophotometric determination of DNA hybridization from renaturation rates. Syst Appl Microbiol 4, 184-192.

Kämpfer, P., Witzenberger, R., Denner, E. B. M., Busse, H.-J. \& Neef, A. (2002). Sphingopyxis witflariensis sp. nov., isolated from activated sludge. Int J Syst Evol Microbiol 52, 2029-2034.

Kates, M. (1986). Techniques of Lipidology, 2nd edn. Amsterdam: Elsevier.

Kim, M. K., Im, W.-T., Ohta, H., Lee, M. \& Lee, S.-T. (2005). Sphingopyxis granuli sp. nov., a $\beta$-glucosidase-producing bacterium in the family Sphingomonadaceae in $\alpha-4$ subclass of the Proteobacteria. J Microbiol 43, 152-157.

Kim, B.-S., Lim, Y. W. \& Chun, J. (2008). Sphingopyxis marina sp. nov. and Sphingopyxis litoris sp. nov., isolated from seawater. Int J Syst Evol Microbiol 58, 2415-2419.

Lee, J.-S., Shin, Y. K., Yoon, J.-H., Takeuchi, M., Pyun, Y.-R. \& Park, Y.-H. (2001). Sphingomonas aquatilis sp. nov., Sphingomonas koreensis sp. nov. and Sphingomonas taejonensis sp. nov., yellow-pigmented bacteria isolated from natural mineral water. Int J Syst Evol Microbiol 51, 1491-1498.

Lee, M., Ten, L. N., Lee, H.-W., Oh, H. W., Im, W.-T. \& Lee, S.-T. (2008). Sphingopyxis ginsengisoli sp. nov., isolated from soil of a ginseng field in South Korea. Int J Syst Evol Microbiol 58, 2342-2347.

Margesin, R., Gander, S., Zacke, G., Gounot, A. M. \& Schinner, F. (2003). Hydrocarbon degradation and enzyme activities of coldadapted bacteria and yeasts. Extremophiles 7, 451-458.

Pal, R., Bhasin, V. K. \& Lal, R. (2006). Proposal to reclassify [Sphingomonas] xenophaga Stolz et al. 2000 and [Sphingomonas] taejonensis Lee et al. 2001 as Sphingobium xenophagum comb. nov. and Sphingopyxis taejonensis comb. nov., respectively. Int J Syst Evol Microbiol 56, 667-670.

Sambrook, J., Frisch, E. F. \& Maniatis, T. (1989). Molecular Cloning: $a$ Laboratory Manual, 2nd edn. Cold Spring Harbor, NY: Cold Spring Harbor Laboratory.

Sasser, M. (1990). Identification of bacteria by gas chromatography of cellular fatty acids, MIDI Technical Note 101. Newark, DE: MIDI Inc.

Stolz, A., Busse, H.-J. \& Kämpfer, P. (2007). Pseudomonas knackmussii sp. nov. Int J Syst Evol Microbiol 57, 572-576.

Takeuchi, M., Kawai, F., Shimada, Y. \& Yokota, A. (1993). Taxonomic study of polyethylene glycol-utilizing bacteria: emended description of the genus Sphingomonas and new descriptions of Sphingomonas macrogoltabidus sp. nov., Sphingomonas sanguis sp. nov. and Sphingomonas terrae sp. nov. Syst Appl Microbiol 16, 227-238.

Takeuchi, M., Hamana, K. \& Hiraishi, A. (2001). Proposal of the genus Sphingomonas sensu stricto and three new genera, Sphingobium, Novosphingobium and Sphingopyxis, on the basis of phylogenetic and chemotaxonomic analyses. Int J Syst Evol Microbiol 51, 14051417.

Vancanneyt, M., Schut, F., Snauwaert, C., Goris, J., Swings, J. \& Gottschal, J. C. (2001). Sphingomonas alaskensis sp. nov., a dominant bacterium from a marine oligotrophic environment. Int J Syst Evol Microbiol 51, 73-79.

Wayne, L. G., Brenner, D. J., Colwell, R. R., Grimont, P. A. D., Kandler, O., Krichevsky, M. I., Moore, L. H., Moore, W. E. C., Murray, R. G. E. \& other authors (1987). International Committee on Systematic Bacteriology. Report of the ad hoc committee on reconciliation of approaches to bacterial systematics. Int J Syst Bacteriol 37, 463-464.

Wu, C., Lu, X., Qin, M., Wang, Y. \& Ruan, J. (1989). Analysis of menaquinone compound in microbial cells by HPLC. Microbiology [English translation of Microbiology (Beijing)] 16, 176-178.

Yabuuchi, E., Yano, I., Oyaizu, H., Hashimoto, Y., Ezaki, T. \& Yamamoto, H. (1990). Proposals of Sphingomonas paucimobilis gen. nov. and comb. nov., Sphingomonas parapaucimobilis sp. nov., Sphingomonas yanoikuyae sp. nov., Sphingomonas adhaesiva sp. nov., Sphingomonas capsulata comb. nov., and two genospecies of the genus Sphingomonas. Microbiol Immunol 34, 99-119.

Yabuuchi, E., Kosako, Y., Fujiwara, N., Naka, T., Matsunaga, I., Ogura, H. \& Kobayashi, K. (2002). Emendation of the genus Sphingomonas Yabuuchi et al. 1990 and junior objective synonymy of the species of three genera, Sphingobium, Novosphingobium and Sphingopyxis, in conjunction with Blastomonas ursincola. Int J Syst Evol Microbiol 52, 1485-1496.

Yoon, J.-H. \& Oh, T.-K. (2005). Sphingopyxis flavimaris sp. nov., isolated from sea water of the Yellow Sea in Korea. Int J Syst Evol Microbiol 55, 369-373.

Yoon, J.-H., Lee, C.-H., Yeo, S.-H. \& Oh, T.-K. (2005). Sphingopyxis baekryungensis sp. nov., an orange-pigmented bacterium isolated from sea water of the Yellow Sea in Korea. Int J Syst Evol Microbiol 55, 1223-1227.

Zhang, D.-C., Wang, H.-X., Liu, H.-C., Dong, X.-Z. \& Zhou, P.-J. (2006). Flavobacterium glaciei sp. nov., a novel psychrophilic bacterium isolated from the China No.1 glacier. Int J Syst Evol Microbiol 56, 2921-2925. 